Brazilian Journal

of Chemical

Engineering

\title{
REGULATED AIR POLLUTANT EMISSIONS FROM HIGHER EMITTERS STATIONARY SOURCES IN BELO HORIZONTE, MINAS GERAIS, BRAZIL
}

\author{
Fábio S. Santos ${ }^{1}$, Gisele A. Miranda ${ }^{1}$, Amanda N. M. Carvalho', \\ Vanessa S. B. Carvalho ${ }^{2}$ and Taciana T. de A. Albuquerque ${ }^{1,3^{*}}$ \\ ${ }^{1}$ Universidade Federal de Minas Gerais, Departamento de Engenharia Sanitária e Ambiental, Belo Horizonte, MG, Brasil. \\ E-mail: fabiosoares04@gmail.com - ORCID: 0000-0002-1753-9323; gisele.alvesmiranda@gmail.com - ORCID: 0000-0001-7297-9746; \\ amanda.nmc@gmail.com - ORCID: 0000-0001-8291-1438; taciana@desa.ufmg.br - ORCID: 0000-0002-6611-0283 \\ ${ }^{2}$ Universidade Federal de Itajubá, Instituto de Recursos Naturais, Itajubá, MG, Brasil. E-mail: vanessa.silveira@unifei.edu.br - \\ ORCID: 0000-0001-7177-6381 \\ ${ }^{3}$ Universidade Federal do Espírito Santo, Programa de Pós-Graduação em Engenharia Ambiental, Vitória, ES, Brasil.
}

(Submitted: July 26, 2018 ; Revised: December 2, 2018 ; Accepted: December 20, 2018)

\begin{abstract}
Belo Horizonte, capital of Minas Gerais state, is a highly urbanized city located in the third largest metropolitan area of Brazil, being one of the most important cities in the country. There are several potential air pollutant emission sources in the studied area, such as industry and the vehicular fleet $(1,669,884$ vehicles in 2015). These can affect the air quality, which can have an impact on population health. Despite this critical scenario, few studies have been developed with the objective of evaluating the air quality in this city, especially regarding the identification of pollutant emission sources. Thus, the aim of this study was to identify and quantify atmospheric emissions by stationary sources of significant environmental impact in Belo Horizonte. The quantification of emissions was preferably performed based on chimneys monitoring data. However, in the absence of these data, estimates were made based on AP-42 guidelines. As a result, 75 chimneys were identified, belonging to 28 companies. Pollutant emission rates of 305, 235, 234, 224, 206, 180 and 63 t year ${ }^{-1}$ were observed for $\mathrm{NO}_{\mathrm{X}}, \mathrm{CO}, \mathrm{TSP}, \mathrm{PM}_{10}, \mathrm{PM}_{2.5}, \mathrm{SO}_{2}$ and $\mathrm{VOC}$, respectively. The results obtained can contribute to the diagnosis, modeling and management of air quality in Belo Horizonte.

Keywords: Air pollution; Emission source; Emission inventory; Chimneys.
\end{abstract}

\section{INTRODUCTION}

Belo Horizonte, capital of Minas Gerais state, is a highly urbanized city located in the third largest metropolitan area of Brazil, which receives the city's name. This municipality has a population of over 2.5 million inhabitants, an area of $331 \mathrm{~km}^{2}$, resulting in a population density of 7,167 inhabitants $\mathrm{km}^{-2}$. Its Human Development Index (HDI) is 0.810 and the Gross Domestic Product (GDP) is 81.43 billion reais (R\$), which represents $16.7 \%$ of the state GDP and $1.53 \%$ of the national GDP. In an economic view, Belo Horizonte is one of the most important cities in Brazil (IBGE, 2016).
In Belo Horizonte, there are many potential emission sources of atmospheric pollutants, such as the steel industry, several industrial boilers, for example, in hospitals, hotels and laundries, and pollutants related to the high growth of the vehicular fleet, which increased from 659,672 to $1,669,884$ vehicles (growth of $153 \%$ ) between 2000 and 2015 (DENATRAN, 2016). Associated with the urban network expansion, these emission sources can affect the air quality, causing damage to the population health, as observed in Freitas et al. (2013) and Radicchi (2012), as well as to the environment. Despite this critical scenario, few studies have been carried out focusing on atmospheric

\footnotetext{
* Corresponding author: Taciana T. de A. Albuquerque - E-mail: taciana@desa.ufmg.br
} 
pollution for this city, especially in relation to identification of emission sources and evaluation of dispersion and environmental contamination processes. For example, the only atmospheric emission inventory for Belo Horizonte (Table 1) was published by the state environmental agency (Fundação Estadual de Meio Ambiente) in 2003 (FEAM, 2003), but the aspect of emissions distribution over time was not considered. This scenario is very common in other Brazilian areas, where few studies have reported atmospheric emissions and there is a lack of data updating (Table 1).

Although on-road vehicles are reported as the main sources of air pollutants in urban environments, stationary sources, such as chimneys from industry, boilers and furnaces, may still make significant contributions to air pollution on these areas. According to Carvalho et al. (2015), industry still plays an important role for air pollution problems in some urban cities, as observed in the Metropolitan Area of São Paulo. Furthermore, Bhanarkar et al. (2005) showed that fossil fuel combustion in boilers is a significant source of sulfur dioxide, particles and toxic metals that can deteriorate air quality in urban areas. It is also important to consider that the major problems related to air pollution are due to the synergism of sources, it being necessary to know the main types of sources and emitted pollutants in a given study area. All of these issues are problems related to air quality that may be occurring in Belo Horizonte.

In order to define strategies and policies to mitigate the adverse effects of exposure to atmospheric pollutants, it is necessary to have a full comprehension of its characteristics and dynamics in urban environments. One of the most important steps to achieve this goal, is to identify the sources and quantify the pollutant emission rates, which is realized through an emission inventory (González et al., 2017). Through this tool, it is possible to identify the predominant emission sources and understand the main sectors and types of pollutants that contribute to the air quality deterioration in a given locality (Qiu et al., 2014; Ueda and Tomaz, 2011; Zhou et al., 2014).
In this context, the identification of stationary sources of air pollutants, in conjunction with their emission profiles in space and time, can provide a better understanding of their contribution to atmospheric emissions in Belo Horizonte nowadays. Pollutant emission quantification in these sources is also a fundamental subsidy for atmospheric dispersion studies, with models such as AERMOD (American Meteorological Society and Environmental Protection Agency Regulatory Model), and for assessing air quality through photochemical models, such as CMAQ (Community Multi-Scale Air Quality) (Albuquerque et al., 2018, Borge et al., 2008, 2014, Kim et al., 2008).

Thus, the aim of this study was to identify and quantify atmospheric emissions by stationary sources (chimneys) from companies of significant environmental impact in Belo Horizonte, with 2015 as the baseline year. Moreover, this study aimed to allocate these atmospheric emissions in space and time, and to evaluate the uncertainties associated with the use of emission factors for atmospheric emissions estimates.

\section{METHODOLOGY}

\section{Selection of companies and data acquisition}

The first stage to identify and quantify atmospheric emissions from stationary sources consisted in the selection of companies with significant potential air pollution impact, which are licensed and located in Belo Horizonte and whose environmental licenses were granted by the municipality or by the state. For this, research was carried out at the Municipal Secretariat of Environment of Belo Horizonte (SEMMA) and at the State Secretariat of Environment and Sustainable Development of Minas Gerais (SEMAD).

The polluting potential classification was made according to the guidelines of the Normative Deliberation 74/2004 of the Conselho Estadual de Política Ambiental (State Council of Environmental Policy) (COPAM) (MINAS GERAIS, 2004) and according to the Normative Deliberation 74/2012 of the Conselho Municipal de Meio Ambiente (Municipal Council of the Environment) (COMAM) (BELO

Table 1. Atmospheric emissions by stationary sources in Brazilian areas.

\begin{tabular}{cccccccc}
\hline \multirow{2}{*}{ Local } & \multirow{2}{*}{ Reference } & Baseline & \multicolumn{4}{c}{ Emission $\left[\mathbf{t ~ y e a r} \mathbf{k m}^{-2}\right]$} \\
\cline { 5 - 8 } & & year & TSP & SO $_{\mathbf{2}}$ & CO & NOX & VOC \\
\hline Belo Horizonte & (FEAM, 2003) & 2002 & 1.0 & 0.1 & 1.9 & 5.2 & 0.1 \\
Contagem & (FEAM, 2003) & 2002 & 3.6 & 2.2 & 9.5 & 41.7 & 1.3 \\
Betim & (FEAM, 2003) & 2002 & 6.1 & 21.9 & 4.8 & 45.8 & 1.2 \\
MASP & (CETESB, 2016) & 2014 & 0.4 & 0.7 & 0.5 & 3.3 & 0.7 \\
MAV & (IEMA, 2011) & 2010 & 3.9 & 9.7 & 60.0 & 9.1 & 2.0 \\
MARJ & (Pires, 2005) & 2004 & 1.9 & 9.8 & 1.1 & 5.3 & 4.5 \\
MAS & (Lyra, 2008) & 2006 & 0.9 & 4.3 & 5.8 & 5.9 & 2.8 \\
Curitiba & (Grauer et al., 2013) & 2013 & 4.4 & 0.3 & 22.0 & 2.7 & NA $^{1}$ \\
\hline
\end{tabular}

${ }^{1}$ NA: Not Available; MASP = Metropolitan Area of São Paulo; MAV = Metropolitan Area of Vitória; MARJ = Metropolitan Area of Rio de Janeiro; MAS = Metropolitan Area of Salvador. 
HORIZONTE, 2012), state and municipal legislations, respectively. These legislations establish criteria for classifying companies and activities that may be subject to environmental licensing, according to their size and polluting potential of air, soil and water. The polluting potential is a function of the intrinsic activity characteristics, considering mainly effluent flow rates and types of pollutants emitted.

At SEMMA, the identification of companies with significant air polluting potential was done with the assistance of technicians from the sector of Industrial Activities Licensing, who listed these companies according to the environmental licensing protocols. After the identification phase, consultations were carried out on the environmental licensing processes of the companies, such as environmental impact studies, environmental performance evaluation reports and environmental monitoring and compliance reports.

Considering that SEMAD provides the environmental information of companies licensed in the state, in electronic format, on the portal of the Integrated Environmental Information System (SIAM, 2017), searches in this database were then performed by linking the activity code and the name of the municipality. Through this, it was possible to identify the companies on which more refined searches were made in order to collect their respective environmental information.

At SEMMA and SEMAD, consultations of the environmental licensing processes were necessary to collect the following information: types, names and quantities of the emission sources; physical parameters such as location, diameter and height of the source; monitoring data of emitted pollutants, such as flow, velocity, temperature, concentration and emission rates. Information was also necessary on the production processes, such as daily operating time, raw materials used, fuel consumption rates, and whether or not emission control systems existed. It is important to emphasize that the monitoring data came from certified laboratories, whose methods of collection and analysis are recommended by technical standards, such as the Associação Brasileira de Normas Técnicas (Brazilian Association of Technical Standards) (ABNT), the United States Environmental Protection Agency (US EPA) and the Companhia Ambiental do Estado de São Paulo (Environmental Company of São Paulo State) (CETESB).

\section{Atmospheric emissions estimates}

After the data acquisition for each company to be inventoried, air pollutant emissions estimates were carried out in two ways. In the first one, emission rates were extracted directly from the monitoring data. However, not all companies had monitoring data on their pollutants and / or not all pollutants that could be emitted were monitored. In those cases, estimates were made following the guidelines of the Compilation of Air Pollutant Emission Factors (AP-42) from the United States Environmental Protection Agency (US EPA, 1995). This methodology follows the emission factor $(\mathrm{EF})$ approach, as demonstrated in Equation 1:

$$
\mathrm{E}=\mathrm{A} \times \mathrm{EF} \times\left(1-\frac{\mathrm{RE}}{100}\right)
$$

where $E$ is pollutant emission $\left(\mathrm{kg} \mathrm{h}^{-1}\right) ; A$ is the activity, which can be, for example, the fuel consumption, the activity duration or the amount of produced material; $E F$ is the emission factor, which relates the mass of pollutant emitted with the activity; and $R E$ is the removal efficiency of the control equipment adopted at the emission source (\%).

Emission factors were taken from the AP-42 (US EPA, 1995), European Environmental Agency (EEA, 2016) and UK National Emissions Inventory (JONES et al., 2017). Although the EFs used are from the US EPA database or from European Union countries, in the absence of local EFs, their use has been recurrent and accepted in several studies developed worldwide, such as Pires (2005) (Rio de Janeiro, Brazil), Sadavarte and Venkataraman (2014) (India), Kawashima (2015) (Brazil) and González et al. (2017) (Colombia).

\section{Spatial and temporal allocation of emissions}

The spatial allocation of the emission sources was done according to their geographical coordinates in ArcGIS (version 10.3). The temporal distribution was based on data for the productive processes. Thus, for continuous processes, constant emission rates (24 hours per day) were used throughout the reference year. For cases where production was interrupted or changed according to the hours of the day or to the days of the week, the emission rates were distributed according to these periods. In cases where information on the production process was unavailable, the most conservative scenario was adopted, with emission rates constant 24 hours a day, 7 days a week.

\section{Assessment of uncertainties associated with the use of emission factors}

Considering the intrinsic uncertainties related to the use of emission factors, an evaluation of the existence of differences between the data obtained from the monitoring and those estimated from these emission factors was performed. Thus, for those sources estimated from monitoring data, where data were also available to estimate their emissions based on emission factors if their pollutants had not been monitored, these two methodologies were used.

Subsequently, the percentage error observed in the estimate based on the emission factor was calculated in 
comparison to the data obtained from the monitoring, as presented in Equation 2. This process allowed a preliminary evaluation of uncertainties arising from the use of emission factors.

$$
\operatorname{Error}(\%)=\left[\frac{\left(\mathrm{E}_{\mathrm{EF}}-\mathrm{E}_{\text {Monitoring }}\right)}{\mathrm{E}_{\text {Monitoring }}}\right] \times 100
$$

where Error (\%) is the percentage error observed in the estimate based on the emission factor; $E_{E F}$ is emission rate of a given pollutant obtained from the emission factors; $E_{\text {Monitoring }}$ is the emission rate of a given pollutant obtained from the monitoring data.

\section{RESULTS AND DISCUSSIONS}

\section{Atmospheric emissions from stationary sources in Belo Horizonte}

Based on the methodologies outlined, 75 stationary sources of atmospheric pollutants were identified in Belo Horizonte, distributed over 28 companies. Among these sources, there are 21 boiler chimneys supplied with low flash point fuel oil (BPF A1 oil) (9), firewood (5), natural gas (3) and liquefied petroleum gas (LPG) (1), and 36 chimneys from a single steel industry. These results represented a significant change compared to the local official inventory (FEAM, 2003), with the inclusion of 25 new companies and maintenance of only 3 of the previously reported.

The inventoried air pollutants considered were those regulated by the Normative Deliberation 491/2018 of the Conselho Nacional de Meio Ambiente (National Environment Council) (CONAMA) (BRASIL, 2018) that directly affect the air quality, with impact on health and on the environment. These pollutants were total suspended particles (TSP) and their fractions, particulate matter with an average aerodynamic diameter of less than $10 \mu \mathrm{m}\left(\mathrm{PM}_{10}\right)$ and less than 2.5 $\mu \mathrm{m}\left(\mathrm{PM}_{2.5}\right)$, sulfur dioxide $\left(\mathrm{SO}_{2}\right)$, carbon monoxide $(\mathrm{CO})$ and nitrogen oxide $\left(\mathrm{NO}_{\mathrm{x}}\right)$. Although volatile organic compounds (VOC) were not included in these legislations, they were also considered due to their important role in ozone formation.

Among the pollutants evaluated, considering an overall rate (sum of all sources) in the base year of this study (2015), $\mathrm{NO}_{\mathrm{X}}$ was the most emitted, with an emission rate of $305 \mathrm{t}^{\mathrm{year}}{ }^{-1}$ (Figure 1). The emission of this pollutant is closely associated with combustion processes due to the thermal combination at high temperatures of nitrogen $\left(\mathrm{N}_{2}\right)$ and oxygen $\left(\mathrm{O}_{2}\right)$ present in atmospheric air (Zeldovich mechanism). In the case of stationary sources in Belo Horizonte, $\mathrm{NO}_{\mathrm{x}}$ emissions occurred mainly in industrial boilers (companies 6,8 and 13 to 17 , Table 2), in biogas burning plants

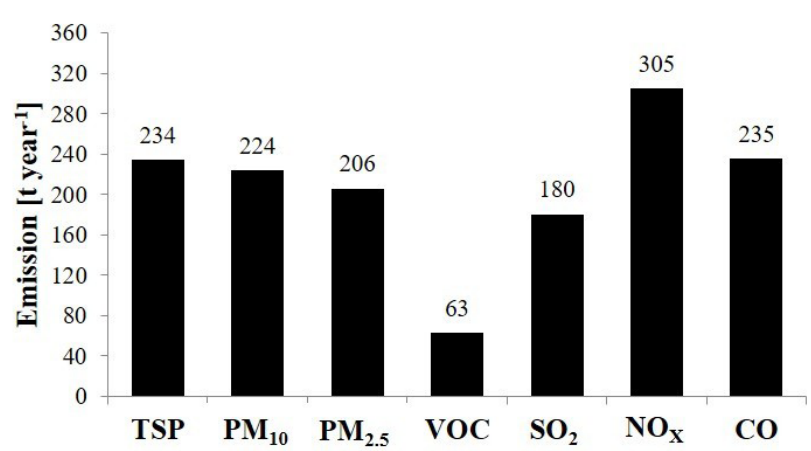

Figure 1. Emission rates of air pollutants by stationary sources in Belo Horizonte in 2015.

(company 27, Table 2) and in steelworks (company 28, Table 2).

$\mathrm{CO}$ was the second most emitted pollutant in stationary sources in Belo Horizonte in 2015, with an annual emission of 235 tons (Figure 1). As for $\mathrm{NO}_{\mathrm{X}}$, this emission is also related to combustion processes due to incomplete fuel oxidation. The highest emission rates were mainly observed for companies that had wood fired boilers (companies 5 to 9, Table 2), BPF 1 A oil boiler (company 13, Table 2), and the biogas and steel industry (companies 27 and 28, respectively; Table 2).

In the case of particles, both TSP and its fractions, $\mathrm{PM}_{10}$ and $\mathrm{PM}_{25}$, emission rates were higher than 200 $t_{\text {year-1 }}$ (Figure 1). In this case, besides the particulate matter emission in the combustion processes, physical processes of grinding, transportation and materials finishing also contributed with their respective rates. Thus, in Table 2 it can be observed that the steel industry (company 28) was responsible for 81, 82 and $85 \%$ of TSP, $\mathrm{PM}_{10}$ and $\mathrm{PM}_{2.5}$, respectively, emitted by stationary sources inventoried in Belo Horizonte. The main reasons are related to the large number of sources (36 sources) and developed processes, such as transportation, loading and unloading of particulate raw materials, combustion in various types of furnaces, as well as the finishing of materials, such as blasting and painting. Nevertheless, significant contributions also came from companies 5 and 8 (wood fired boilers) and 13 and 16 (oil boilers) (Table 2).

It is important to emphasize that, out of the 234 $\mathrm{t}$ year $^{-1}$ emitted of TSP, the biggest part corresponds to its fractions $\mathrm{PM}_{10}(96 \%)$ and $\mathrm{PM}_{2.5}(88 \%)$. This close proximity between TSP and its fractions may be related to combustion systems, which form mostly fine particles. In addition, especially in industrial boilers, control systems, such as cyclones, are designed primarily for the removal of coarse particles, which results in higher emission of fine particles.

Since $\mathrm{PM}_{2.5}$ is composed of particles with small diameters that are able to penetrate deeply into the pulmonary alveoli and the cardiovascular system, thus putting human health at risk, the high emission rates of 
Table 2. Atmospheric emissions by typologies of stationary sources in Belo Horizonte in 2015.

\begin{tabular}{|c|c|c|c|c|c|c|c|c|}
\hline \multicolumn{2}{|r|}{ Company } & \multicolumn{7}{|c|}{ Emission $\left[t\right.$ year $\left.{ }^{-1}\right]$} \\
\hline $\mathbf{N}^{0}$. & Typology / Activity & TSP & $\mathbf{P M}_{10}$ & $\mathbf{P M}_{2.5}$ & VOC & $\mathbf{S O}_{2}$ & $\mathbf{N O}_{\mathbf{X}}$ & $\mathrm{CO}$ \\
\hline 1 & Production of malt and beer & 0.02 & 0.02 & 0.02 & 0.01 & 0.02 & 0.24 & 0.20 \\
\hline 2 & Production of pharmaceutical products & 0.04 & 0.04 & 0.04 & 0.01 & 0.02 & 0.23 & 0.22 \\
\hline 3 & Manufacturing of vests, helmets and ballistic plates & 0.07 & 0.07 & 0.07 & 1.10 & 0.05 & 0.02 & 0.95 \\
\hline 4 & Production of malt and beer & 0.01 & 0.01 & 0.01 & 0.01 & 0.01 & 0.10 & 0.05 \\
\hline 5 & Industrial laundry & 6.87 & 6.18 & 5.22 & 20.79 & 13.33 & 0.47 & 7.74 \\
\hline 6 & $\begin{array}{l}\text { Bleaching and dyeing in yarns, fabrics and textile } \\
\text { articles }\end{array}$ & 2.60 & 2.34 & 1.97 & 0.30 & 0.19 & 3.78 & 10.55 \\
\hline 7 & $\begin{array}{l}\text { Slaughterhouse: slaughtering of cattle and pigs, } \\
\text { manufacturing of meat products and preparation of } \\
\text { slaughter by-products }\end{array}$ & 1.15 & 1.05 & 0.62 & 0.09 & 0.05 & 0.10 & 23.65 \\
\hline 8 & $\begin{array}{l}\text { Production of prefabricated concrete and } \\
\text { industrialization of building materials }\end{array}$ & 16.82 & 15.14 & 12.78 & 2.44 & 1.57 & 30.71 & 91.01 \\
\hline 9 & $\begin{array}{l}\text { Manufacture of sealing adhesives and rubber } \\
\text { products }\end{array}$ & 0.98 & 0.88 & 0.74 & 0.11 & 0.07 & 1.34 & 2.38 \\
\hline 10 & Industrial laundry & 0.16 & 0.16 & 0.15 & 0.01 & 0.79 & 0.45 & 0.04 \\
\hline 11 & Manufacture of rubber products & 0.01 & 0.01 & 0.01 & 0.00 & 0.01 & 0.11 & 0.84 \\
\hline 12 & Hospital boiler & 0.17 & 0.16 & 0.04 & 0.04 & 2.94 & 1.66 & 0.52 \\
\hline 13 & Hospital boiler & 7.63 & 6.56 & 4.27 & 1.94 & 40.24 & 42.87 & 7.59 \\
\hline 14 & Hospital boiler & 1.26 & 1.08 & 0.70 & 0.16 & 49.28 & 6.91 & 0.63 \\
\hline 15 & Hospital boiler & 0.73 & 0.63 & 0.41 & 0.09 & 28.81 & 4.04 & 0.37 \\
\hline 16 & Hospital boiler & 2.71 & 2.57 & 0.60 & 0.39 & 24.97 & 17.40 & 0.43 \\
\hline 17 & Hospital boiler & 1.43 & 1.23 & 0.80 & 0.18 & 4.53 & 7.85 & 0.71 \\
\hline 18 & Production of soft drinks & 0.03 & 0.03 & 0.02 & 0.04 & 0.03 & 1.65 & 0.15 \\
\hline 19 & Organic electronics laboratory & 0.00 & 0.00 & 0.00 & 0.04 & 0.00 & 0.00 & 0.00 \\
\hline 20 & $\begin{array}{l}\text { Manufacturing of building articles (sinks, tanks and } \\
\text { washbasins in synthetic marble) }\end{array}$ & 0.84 & 0.84 & 0.84 & 0.21 & 0.00 & 0.00 & 0.00 \\
\hline 21 & $\begin{array}{l}\text { Manufacturing of machinery and equipment for } \\
\text { mining }\end{array}$ & 0.12 & 0.12 & 0.12 & 0.00 & 0.00 & 0.00 & 0.00 \\
\hline 22 & $\begin{array}{l}\text { Manufacturing of machinery, equipment and } \\
\text { apparatus for loads transport and elevation }\end{array}$ & 1.49 & 1.49 & 1.49 & 2.47 & 0.00 & 0.00 & 0.00 \\
\hline 23 & Crematorium & 0.19 & 0.17 & 0.17 & 0.03 & 0.26 & 0.67 & 0.17 \\
\hline 24 & Production of printed circuit boards & 0.03 & 0.03 & 0.03 & 0.00 & 0.00 & 0.00 & 0.00 \\
\hline 25 & Production of voltaic films & 0.00 & 0.00 & 0.00 & 0.01 & 0.00 & 0.00 & 0.00 \\
\hline 26 & Production of concrete & 0.03 & 0.03 & 0.03 & 0.00 & 0.00 & 0.00 & 0.00 \\
\hline 27 & $\begin{array}{l}\text { Production of energy from the burning of landfill } \\
\text { biogas }\end{array}$ & 0.00 & 0.00 & 0.00 & 0.00 & 7.34 & 49.51 & 11.65 \\
\hline 28 & $\begin{array}{l}\text { Steel industry: steelmaking and processing of iron } \\
\text { and steel products with ores reduction, including pig } \\
\text { iron }\end{array}$ & 189.03 & 183.22 & 174.51 & 32.43 & 5.59 & 134.58 & 75.19 \\
\hline
\end{tabular}

this pollutant observed in the present study are a point of attention. According to Andreão et al. (2018), in 2013 and 2014, the concentration of $\mathrm{PM}_{25}$ in the Belo Horizonte atmosphere was higher than the standards established by the World Health Organization (WHO) $\left(10 \mu \mathrm{g} \mathrm{cm}^{-3}\right)$. The sources studied here may be potential contributors to this exceeding of the standards.

For $\mathrm{SO}_{2}$, emissions occur due to the presence of sulfur in the fuels, which, during the combustion processes, is oxidized and converted into gas. In this study, $\mathrm{SO}_{2}$ emissions were 180 t year $^{-1}$ (Figure 1), with burning of fuel oil in industrial boilers, especially in companies 13 to 16 (Table 2), as the main contributor.

Finally, the least emitted pollutant was VOC, also formed during the combustion processes (incomplete oxidation), in addition to evaporative emissions in painting booths. Its total emission rate was $63 \mathrm{t}^{\text {year }}{ }^{-1}$ (Figure 1), with the largest contributions coming from the steel industry (company 28) and from an industrial boiler with high consumption of firewood (company 5) (Table 2).

In the present study, only stationary sources for which licensing processes are required by the environmental agency were considered. Despite this, Kumar et al. (2016), evaluating the challenges of air quality management in the Metropolitan Area of São Paulo (MASP), reported the influence of unregulated sources on air quality, such as bakery chimneys, restaurants, pizzerias and steakhouses. In the case of pizzerias, Lima (2015) showed that, in the city of São Paulo there are about 8,000 pizzerias, of which approximately $80 \%$ use firewood in their kilns. Considering an average utilization rate of 48 tons of firewood per year per pizzeria, Lima (2015) estimated an emission rate of approximately $321 \mathrm{~kg} \mathrm{day}^{-1}$ of $\mathrm{PM}_{2.5}$. These issues show the need of improving the inventory with the incorporation of these other typologies of stationary sources, as well as to alert 
public authorities to the surveillance of other potential emission sources, which in previous scenarios did not exist or were considered to be low environmental impact agents.

Along with the observed contribution of the typologies of stationary sources for atmospheric emissions in Belo Horizonte in this study, in many urban areas, other sources, such as vehicular ones, have been reported to be the most representative. Considering the same baseline year of the present study, Santos (2018) estimated the atmospheric emissions of TSP, VOC, $\mathrm{SO}_{2}, \mathrm{NO}_{\mathrm{x}}$ and $\mathrm{CO}$ pollutants as 1,220, 4,616, $581,13,992$ and $16,574 \mathrm{t}^{y^{2}} \mathrm{ear}^{-1}$, respectively, by the vehicular fleet in Belo Horizonte. The emission rates were, respectively, 5.2, 73.4, 3.2, 45.8 and 70.5 times higher than the emissions from the stationary sources inventoried in the present study.

One way to identify which sources have contributed most to the deterioration of local air quality is to monitor the environmental concentrations of certain trace pollutants, such as particulate matter (Albuquerque et al., 2012; Andrade et al., 2012; Miranda et al., 2012). For Belo Horizonte and its metropolitan area, studies that have monitored and characterized the elemental composition of $\mathrm{PM}_{10}$ (Moura, 2016) and $\mathrm{PM}_{25}$ (Andrade et al., 2012) have mainly attributed the environmental concentrations measured to other source typologies, such as vehicular and mining.

The study developed by Andrade et al. (2012), based on the analysis of $\mathrm{PM}_{2.5}$ elemental composition, with subsequent application of receptor models (principal component analysis, multivariate statistics), identified four main factors that can explain the origin of fine particles in the Belo Horizonte atmosphere. The first one, representing $44 \%$ of the collected mass, was related to particulate emissions from soil dust resuspension, mainly due to the presence of $\mathrm{Si}, \mathrm{K}$, $\mathrm{Ca}, \mathrm{Ti}, \mathrm{Fe}$ and $\mathrm{Br}$. This factor was associated with the mining activities developed around the city and also to the materials transported to and from the mines. Factor 2 , responsible for $13 \%$ of all $\mathrm{PM}_{25}$, was attributed to the burning of diesel, mainly due to the activity of heavy vehicles. The third factor, which represented $12 \%$ of the collected mass, was associated with the formation of the secondary aerosol and also the combustion of fuels in industrial processes (including the inventoried sources). The last factor analysed, representing only $4 \%$ of the collected mass, was linked to the emissions released by the exhaust pipes of light vehicles (Andrade et al., 2012).

Moura (2016), following a similar methodology as Andrade et al. (2012), but focusing on the composition of $\mathrm{PM}_{10}$ in several points of the Metropolitan Area of Belo Horizonte (MABH), also noted the importance of emissions due to mining activities and resuspension of soil dust, and due to vehicular activities.
These results reiterate the necessity of an inventory that encompasses the main type of sources, also considering the synergy between them, making possible a more accurate diagnosis of air pollution in urban areas. Furthermore, dispersion studies and air quality modeling may help to understand the influence of the surrounding areas on pollution in a particular study region, making possible the quantitative evaluation of the impact of mining activities from neighboring municipalities on Belo Horizonte's air quality, as previously reported.

\section{Spatial and temporal distribution of atmospheric emissions from chimneys in Belo Horizonte}

Belo Horizonte is a city with nine main regions: Venda Nova, North, Pampulha, Northeast, Northwest, East, South-Central, West and Barreiro. In relation to the spatial distribution of the identified stationary sources, it was possible to verify that, in regional terms, the Barreiro region was the one that hosted most of the sources identified (42 sources, $62.7 \%$ ) (Figure 2 ). Another important aspect of the spatial distribution is that no stationary sources were observed in Venda Nova or in the North regions. For the other regions of Belo Horizonte, the numbers of sources were very close, 8 of them being located in the West region (10.7 $\%), 6$ in the Northwest (8.0\%), 4 in the South-Central, East and Pampulha (5.3\%) and 2 in the Northeast region $(2.7 \%)$.

The temporal emission profiles can be observed in Figure 3. According to the data collected, 44 (58.7\%) of the 75 identified sources have continuous operation $\left(24 \mathrm{~h} \mathrm{day}^{-1}\right)$ while the others $(31 ; 41.3 \%)$ have different

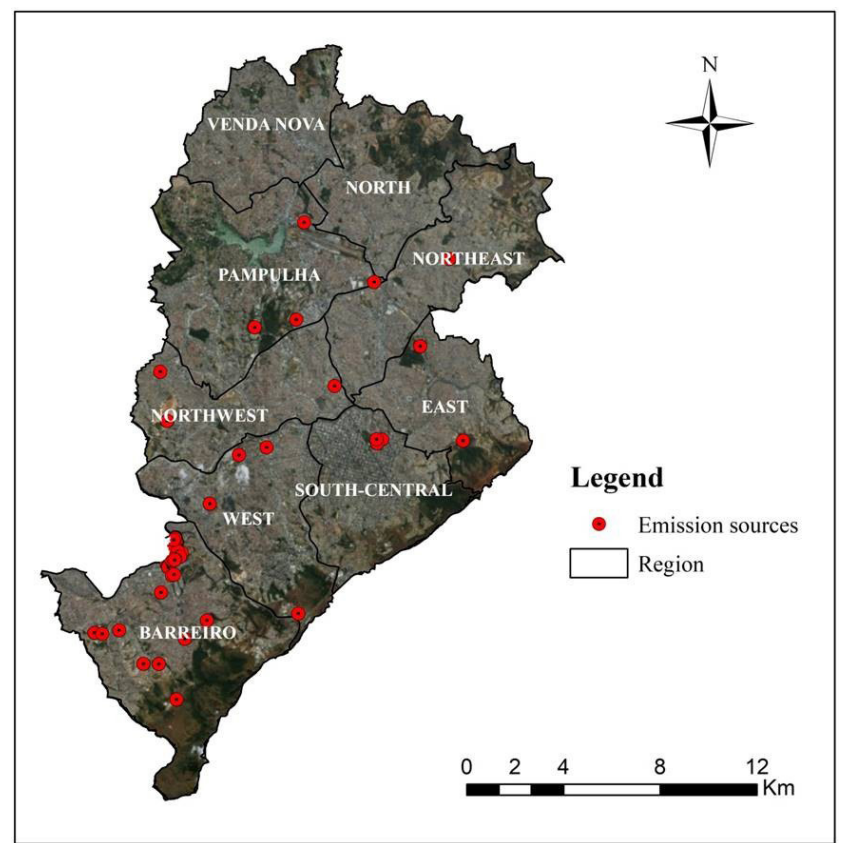

Figure 2. Stationary licensed emission source locations by region in Belo Horizonte in 2015. 


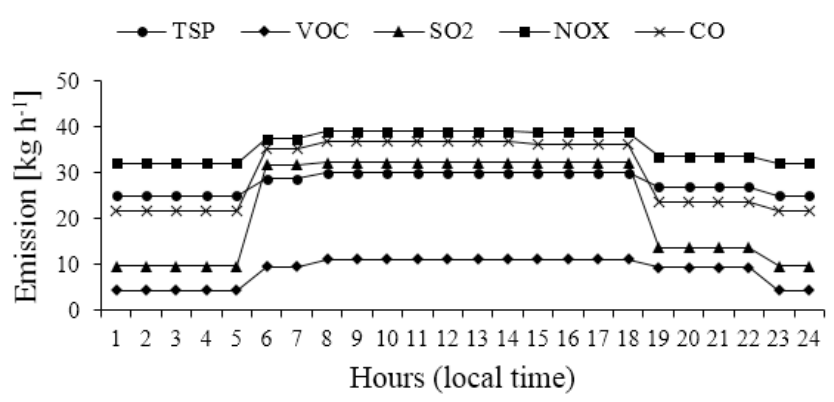

Figure 3. Hourly profiles of atmospheric emissions from stationary sources in Belo Horizonte in 2015.

operating standards, mostly ranging from 6 to $16 \mathrm{~h}^{\text {day }}{ }^{-1}$. As result, for the different pollutants evaluated, three main emission profiles can be observed: a diurnal one from 6 to $18 \mathrm{~h}$ (local time), with the observed emission rates being the highest; one at the end of the day from 18 to $22 \mathrm{~h}$ (local time); and a nocturnal profile from 23 to $5 \mathrm{~h}$ (local time), in which observed emission rates were the lowest.

From these results, it is possible to verify small differences between the end of the day and the nighttime period profiles. Despite this, representative differences can be observed between diurnal profiles and the others, especially for $\mathrm{SO}_{2}$ and $\mathrm{CO}$. Increases in diurnal profiles for these pollutants are due to some activities such as hospital boilers and industrial laundries.

\section{Assessment of uncertainties associated with the use of emission factors}

From the comparison between the emission rates obtained from monitored data and estimates based on emission factors, in situations where the application of these two methodologies was possible, a set of 12 results was obtained for the TSP, 4 for $\mathrm{NO}_{\mathrm{x}}$ and 6 for CO. For $\mathrm{SO}_{2}$ and $\mathrm{VOC}$, it was not possible to carry out this analysis, since most of the data was obtained from estimates. It should also be noted that the data obtained for TSP, $\mathrm{NO}_{\mathrm{x}}$ and $\mathrm{CO}$ were solely related to the combustion processes in boilers, for which only AP-42 emission factors (US EPA, 1995) were used, in order to obtain a more consistent analysis related to the typology of sources. In this sense, due to the presence of isolated cases, the other typologies were not considered in this part of the study.

According to the results obtained, for TSP and $\mathrm{NO}_{\mathrm{x}}$ pollutants, an overestimation in relation to the monitored data was verified, with a mean value of 37.2 and $39.7 \%$, respectively. The opposite profile was observed for $\mathrm{CO}$, in which an average underestimation of $32.6 \%$ was found.

The differences between the data obtained from the monitoring data and those estimated from the emission factors may be due to a number of different causes. The first one is related to uncertainties inherent to the emission factors, as already reported in AP-42 (US EPA, 1995). Other issues that may lead to the overestimation or underestimation of emissions is the lack of specific information about the control systems used, such as the existence or not of control equipment (for those companies for which control information was not reported, non-existence was considered) and the specific removal efficiencies for particulates and gaseous pollutants.

Through advanced statistical analyses, such as uncertainty analyses by the Monte Carlo method, some studies have demonstrated the divergence between data estimated from emission factors and actual data from continuous monitoring. Frey and Zheng (2002) evaluated $\mathrm{NO}_{\mathrm{x}}$ emissions in coal-fired power plants and found total inventory uncertainty ranging from -16 to $19 \%$. These differences were attributed mainly to one of the several technological groups related to the production of thermal energy, suggesting a more accurate process of data collection to establish equivalence between the emission factors and the technology used in the emission source.

Pouliot et al. (2012) also compared estimates from the emission factors of AP-42 with continuous monitoring data of $\mathrm{NO}_{x}$ emissions in an electric power generation plant. According to the data of these researchers, the US EPA emission factors were reasonably representative for some sources, however, the values presented in the AP-42 should be updated, because more than half of the sources were not well represented. For the AP-42 emission factors for this source typology, uncertainties ranging from 25 to 92 $\%$ were observed, with the highest uncertainty values being related to the use of lower quality emission factors.

Frey and Li (2003), evaluating the emissions of several pollutants from stationary engines operating with natural gas, observed mean uncertainties in emission factors of $\pm 10 \%$, but also ranging from -90 to $+180 \%$. According to these authors, the wide range of uncertainties observed in some emission factors emphasizes the importance of recognizing and explaining the limitations of emission estimates.

The results obtained in the present study for the uncertainties generated due to the use of emission factors, despite coming from a small database and presented more generally, without an advanced statistical treatment, show the importance of carrying out emission inventories in a detailed, secure and accurate manner. Methods that consider real data such as continuous monitoring or parametric testing (for example, isokinetic monitoring) should always be prioritized. Estimation using emission factors should be applied only in the cases in which this information is unavailable. Awareness and clarity about the uncertainties generated can help in the 
decision making regarding pollution prevention and control policies, as well as give a better understanding of the results obtained in air quality models, since some studies attribute the poor modeling performance to the emission inventory inaccuracies (Borge et al., 2008; Albuquerque, 2010; Borge et al., 2014; Pedruzzi, 2016). According to Frey and Zheng (2002), if random and biased errors in emission inventories are not quantified, they can lead to erroneous conclusions about emission scenarios, source identification and the relationship between emissions and air quality.

\section{REMARKS AND CONCLUSION}

Based on the applied methodologies, 75 stationary sources of atmospheric pollutants were identified in Belo Horizonte, belonging to 28 companies. It was observed that $\mathrm{NO}_{X}$, among the pollutants evaluated, was the most emitted, followed by CO, TSP, $\mathrm{PM}_{10}$, $\mathrm{PM}_{2.5}, \mathrm{SO}_{2}$ and $\mathrm{VOC}$, with emission rates of 305, 235, 234, 224, 206, 180 and 63 t year $^{-1}$, respectively.

Regarding the spatial distribution of the sources, the Barreiro region was the one that presented the highest concentration of sources, mainly because it is a more industrialized region in the municipality. The temporal distribution showed that, for all pollutants, the daytime period is the one that most contributes to the emission rates, ranging from 6 to $18 \mathrm{~h}$ (local time).

Finally, the uncertainty assessment showed that, in the evaluated cases, the TSP and $\mathrm{NO}_{\mathrm{x}}$ pollutants were, on average, overestimated by 37.2 and $39.7 \%$, respectively, when compared to the monitored data. The opposite profile was observed for $\mathrm{CO}$, in which an average underestimation of $32.6 \%$ was identified. Awareness and clarity about the uncertainties generated can help in the decision-making regarding pollution prevention and control policies, as well as give a better understanding of the results obtained in air quality models, since some studies attribute the poor performance of air quality modeling to emission inventory inaccuracies.

\section{ACKNOWLEDGEMENTS}

The authors thank the National Council for Scientific and Technological Development (CNPq Brazil), Brazilian Federal Agency for Post-graduate Education (CAPES - Brazil) and the Research Support Foundation of the State of Minas Gerais (FAPEMIG) for the postgraduate scholarships and financial resources provided. The authors also thank the sector of Industrial Activities Licensing of Belo Horizonte City Hall for assistance in identifying the emission sources licensed by the municipality.

\section{REFERENCES}

Albuquerque, T. T. A., Andrade, M. F., Ynoue, R. Y. Characterization of atmospheric aerosols in the city of São Paulo, Brazil: Comparisons between polluted and unpolluted periods. Environmental Monitoring and Assessment, 184, 969-984 (2012). https://doi.org/10.1007/s10661-011-2013-y

Albuquerque, T. T. A, Andrade, M. F., Ynoue, R. Y., Moreira, D. M., Andreão, W. L., Santos, F. S., Nascimento, E. G. S. WRF-SMOKE-CMAQ modeling system for air quality evaluation in São Paulo megacity with a 2008 experimental campaign data. Environmental Science and Pollution Research, 25, 1-15 (2018). https://doi.org/10.1007/ s11356-018-3583-9

Albuquerque, T. T. A. Formação e transporte das partículas finas inorgânicas em uma atmosfera urbana: o exemplo de São Paulo. Ph.D. Thesis, Universidade de São Paulo (2010). (In Portuguese).

Andrade, M. F., Miranda, R. M., Fornaro, A., Kerr, A., Oyama, B., Andre, P. A., Saldiva, P. Vehicle emissions and $\mathrm{PM}_{2.5}$ mass concentrations in six Brazilian cities. Air Quality, Atmosphere and Health, 5, 79-88 (2012). https://doi.org/10.1007/s11869-010-0104-5

Andreão, W. L., Albuquerque, T. T. A., Kumar, P. Excess deaths associated with fine particulate matter in Brazilian cities. Atmospheric Environment, 194, 71-81 (2018). https://doi.org/10.1016/j. atmosenv.2018.09.034

BELO HORIZONTE, Deliberação Normativa nº 74 de 10 de outubro de 2012 do Conselho Municipal de Meio Ambiente (Local legislation). COMAM, Belo Horizonte (2012). (In Portuguese).

Bhanarkar, A. D., Rao, P. S., Gajghate, D. G., Nema, $\mathrm{P}$. Inventory of $\mathrm{SO}_{2}, \mathrm{PM}$ and toxic metals emissions from industrial sources in Greater Mumbai, India. Atmospheric Environment, 39, 3851-3864 (2005). https://doi.org/10.1016/j.atmosenv.2005.02.052

Borge, R., Lumbreras, J., Rodríguez, E. Development of a high-resolution emission inventory for Spain using the SMOKE modelling system: A case study for the years 2000 and 2010. Environmental Modelling and Software, 23, 1026-1044 (2008). https://doi.org/10.1016/j.envsoft.2007.11.002

Borge, R., Lumbreras, J., Pérez, J., De La Paz, D., Vedrenne, M., De Andrés, J. M., Rodríguez, M. E. Emission inventories and modelling requirements for the development of air quality plans Application to Madrid (Spain). Science of the Total Environment, 466, 809-819 (2014). https://doi. org/10.1016/j.scitotenv.2013.07.093

BRASIL, Resolução no 491 de 19 de novembro de 2018 do Conselho Nacional de Meio Ambiente. Define os padrões de qualidade do ar nacionais (Local legislation). CONAMA, Brasília (2018). (In Portuguese). 
Carvalho, V. S. B., Freitas, E. D., Martins, L. D., Martins, J. A., Mazzoli, C. R., Andrade, M. F. Air quality status and trends over the Metropolitan Area of São Paulo, Brazil as a result of emission control policies. Environmental Science \& Policy, 47, 68-79 (2015). https://doi.org/10.1016/j. envsci.2014.11.001

CETESB, Companhia Ambiental do Estado de São Paulo, Qualidade do ar no estado de São Paulo 2015. CETESB, São Paulo (2016). (In Portuguese).

DENATRAN, Departamento Nacional de Trânsito. Statistical data - Vehicle fleet. Avalaible in: $<$ http://www.denatran.gov.br/estatistica/237-frotaveiculos $>$. (Accessed: September 09, 2016). (In Portuguese).

EEA, European Environment Agency, EMEP/EEA air pollutant emission inventory guidebook 2016: Technical guidance to prepare national emission inventories. Publications Office of the European Union, Luxembourg (2016).

FEAM, Fundação Estadual do Meio Ambiente, Inventário de fontes emissoras de poluentes atmosféricos, estudo de dispersão atmosférica e projeto da rede otimizada de monitoramento atmosférico para a Região Metropolitana de Belo Horizonte, eixo Belo Horizonte - Contagem - Betim. FEAM, Belo Horizonte (2003). (In Portuguese).

Freitas, C. U., Junger, W., Leon, A. P., Grimaldi, R., Silva, M. A. F. R., Gouveia, N. Poluição do ar em cidades brasileiras: selecionando indicadores de impacto na saúde para fins de vigilância. Epidemiologia e Serviços de Saúde, 22, 445454 (2013). https://doi.org/10.5123/S167949742013000300009

Frey, H. C., Li, S. Methods for quantifying variability and uncertainty in AP-42 emission factors: case studies for natural gas-fueled engines. Journal of the Air \& Waste Management Association, 53, 1436-1447 (2003).

Frey, H. C., Zheng, J. Quantification of variability and uncertainty in air pollutant emission inventories: method and case study for utility $\mathrm{NO}_{\mathrm{x}}$ emissions. Journal of the Air \&Waste Management Association, 52, 1083-1095 (2002). https://doi.org/ 10.1080/10473289.2003.10466317

González, C. M., Gómez, C. D., Rojas, N. Y., Acevedo, H., Aristizábal, B. H. Relative impact of on-road vehicular and point-source industrial emissions of air pollutants in a medium-sized Andean city. Atmospheric Environment, 152, 279-289 (2017). https://doi.org/10.1016/j.atmosenv.2016.12.048

Grauer, A., Malheiros, A. L., Nocko, H. R., Paim, J. B., Souza, B. Inventário estadual de emissões atmosféricas de poluentes ( $\mathrm{MP}, \mathrm{CO}, \mathrm{NO}_{\mathrm{X}}, \mathrm{SO}_{\mathrm{x}}$ ) e proposta para revisão e ampliação da Rede de
Monitoramento da Qualidade do Ar do estado do Paraná. Instituto Ambiental do Paraná, Curitiba (2013). (In Portuguese).

IBGE, Instituto Brasileiro de Geografia e Estatística, Statistical data - Minas Gerais and Belo Horizonte. Available in: < http://cidades.ibge.gov.br/ xtras/perfil.php?codmun $=310620>$. $\quad$ (Accessed: November 03, 2016). (In Portuguese).

IEMA, Instituto Estadual do Meio Ambiente e Recursos Hídricos, Inventário de emissões atmosféricas da Região da Grande Vitória. ECOSOFT, Vitória (2011). (In Portuguese).

Jones, L., Smith, H., Claxton, R., Thistlethwaite, G. Air quality pollutant inventories for England, Scotland, Wales and Northern Ireland: 1990 - 2015. Ricardo Energy \& Environment, London (2017).

Kawashima, A. B. Desenvolvimento de um inventário de emissões atmosféricas por fontes fixas para o Brasil. Master Thesis, Universidade Tecnológica Federal do Paraná (2015). (In Portuguese).

Kim, S., Moon, N., Byun, D. W. Korea emissions inventory processing using the US EPA's smoke system. Asian Journal of Atmospheric Environment, 2, 34-46, 2008. https://doi. org/10.5572/ajae.2008.2.1.034

Kumar, P., Andrade, M. F., Ynoue, R. Y., Fornaro, A., Freitas, E. D., Martins, J., Martins, L. D., Albuquerque, T., Zhang, Y., Morawska, L. New directions: From biofuels to wood stoves: The modern and ancient air quality challenges in the Megacity of São Paulo. Atmospheric Environment, 140, 364-369 (2016). https://doi.org/10.1016/j. atmosenv.2016.05.059

Lima, F. D. M. Quantificação e caracterização físicoquímica do material particulado fino $\left(\mathrm{MP}_{2.5}\right)$ : queima de biomassa em fornos de pizzaria na cidade de São Paulo. Master Thesis, Universidade de São Paulo (2015). (In Portuguese).

Lyra, D. G. P. Modelo integrado de gestão da qualidade do ar da Região Metropolitana de Salvador. Ph.D. Thesis, Universidade Estadual de Campinas (2008). (In Portuguese).

MINAS GERAIS, Deliberação Normativa $n^{\circ} .74$ de 9 de setembro de 2004 do Conselho Estadual de Política Ambiental (Local legislation). COPAM, Belo Horizonte (2004). (In Portuguese).

Miranda, R. M., Andrade, M. F., Fornaro, A., Astolfo, R., Andre, P. A., Saldiva, P. Urban air pollution: A representative survey of $\mathrm{PM}_{2.5}$ mass concentrations in six Brazilian cities. Air Quality, Atmosphere and Health, 5, 63-77 (2012). https://doi.org/10.1007/ s11869-010-0124-1

Moura, I. F. S. Avaliação de $\mathrm{MP}_{10}$ na Região Metropolitana de Belo Horizonte. Master Thesis, Universidade Federal de Minas Gerais (2016). (In Portuguese). 
Pedruzzi, R. Avaliação de desempenho de modelo fotoquímico CMAQ utilizando diferentes condições de contorno em uma região urbana e industrializada. Master Thesis, Universidade Federal do Espírito Santo (2016). (In Portuguese).

Pires, D. O. Inventário de emissões atmosféricas de fontes estacionárias e sua contribuição para a poluição do ar na Região Metropolitana do Rio de Janeiro. Master Thesis, Universidade Federal do Rio de Janeiro (2005). (In Portuguese).

Pouliot, G., Wisner, E., Mobley, D., Hunt, W. Quantification of emission factor uncertainty. Journal of the Air and Waste Management Association, 62, 287-298 (2012). https://doi.org/1 0.1080/10473289.2011.649155

Qiu, P., Tian, H., Zhu, C., Liu, K., Gao, J., Zhou, J., An elaborate high-resolution emission inventory of primary air pollutants for the Central Plain Urban Agglomeration of China. Atmospheric Environment, 86, 93-101 (2014). https://doi. org/10.1016/j.atmosenv.2013.11.062

Radicchi, A. L. A. A poluição na bacia aérea da região metropolitana de Belo Horizonte e sua repercussão na saúde da população. Revista Brasileira de Estudos de População, 29, 195-198, 2012. https:// doi.org/10.1590/S0102-30982012000100013

Sadavarte, P., Venkataraman, C. Trends in multipollutant emissions from a technology-linked inventory for India: I. Industry and transport sectors.
Atmospheric Environment, 99, 353-364 (2014). https://doi.org/10.1016/j.atmosenv.2014.09.081

Santos, F. S. Diagnóstico das emissões atmosféricas em Minas Gerais: um estudo para as fontes fixas e veiculares. Master Thesis, Post-graduate program in Sanitation, Environment and Water Resources, Universidade Federal de Minas Gerais (2018). (In Portuguese).

SIAM, Sistema Integrado da Informação Ambiental, Informações ambientais de empreendimentos licenciados no estado de Minas Gerais. Available in: <http://www.siam.mg.gov.br/siam/processo/ index.jsp $>$. (Accessed January 03, 2017).

Ueda, A. C., Tomaz, E. Inventário de emissão de fontes veiculares da Região Metropolitana de Campinas, São Paulo. Química Nova, 34, 1496$1500 \quad$ (2011). https://doi.org/10.1590/S010040422011000900003

US EPA, United States Environmental Protection Agency, Compilation of air pollutant emission factors. Volume I: Stationary Point and Area Sources. AP-42. 5th Ed. US EPA, Durham (1995).

Zhou, Y., Cheng, S., Chen, D., Lang, J., Zhao, B., Wei, W. A new statistical approach for establishing high-resolution emission inventory of primary gaseous air pollutants. Atmospheric Environment, 94, 392-401 (2014). https://doi.org/10.1016/j. atmosenv.2014.05.047 